\title{
Spindle Cell/Sclerosing Rhabdomyosarcoma
}

National Cancer Institute

\section{Source}

National Cancer Institute. Spindle Cell/Sclerosing Rhabdomyosarcoma. NCI Thesaurus.

Code C121654.

An uncommon variant of rhabdomyosarcoma with spindle cell or sclerosing morphology.

It affects both children and adults and it is more common in males. 